Nguyen Xuan Vy*, Laura Holzmeyer and Jutta Papenbrock

\title{
New record of the seagrass species Halophila major (Zoll.) Miquel in Vietnam: evidence from leaf morphology and ITS analysis
}

\begin{abstract}
The seagrass Halophila major (Zoll.) Miquel is reported for the first time from Vietnam. It was found growing with other seagrass species nearshore, 4-6 m deep at Tre Island, Nha Trang Bay. Leaf morphology and phylogenetic analysis based on ribosomal internal transcribed spacer sequences confirmed the identification. There was very little sequence differentiation among samples of $H$. major collected in Vietnam and other countries in the Western Pacific region. A very low evolutionary divergence among H. major populations was found.
\end{abstract}

Keywords: Halophila major; internal transcribed spacer; new record; seagrass; Vietnam.

\footnotetext{
* Corresponding author: Nguyen Xuan Vy, Institute of Botany, Leibniz University Hannover, Herrenhäuserstr. 2, D-30419 Hannover, Germany, e-mail: nguyenxuanvi@gmail.com; and Institute of Oceanography, Department of Marine Botany, Vietnam Academy of Science and Technology, 01 Cau Da, Nha Trang City, Vietnam Laura Holzmeyer and Jutta Papenbrock: Institute of Botany, Leibniz University Hannover, Herrenhäuserstr. 2, D-30419 Hannover, Germany
}

\section{Introduction}

In Vietnam, two species of Halophila were recorded in 1885: Halophila ovalis (R. Br.) H. f. and H. beccarii Ascherson (Tien 2008). Halophila minor (Zollinger) den Hartog and $H$. decipiens Ostenf. were added to the list of Halophila occurring in Vietnam during a later study (Dai et al. 1998). However, the taxonomic diversity of the genus Halophila has been given little attention until recently. Defining taxonomic boundaries within the genus Halophila has represented a real challenge due to leaf morphological traits that overlap among species (Kuo et al. 2006, Uchimura et al. 2008, Short et al. 2011, Shimada et al. 2012). Halophila major (Zoll.) Miquel [formerly known in Japan as H. euphlebia Makino but recently classified as H. major by Kuo et al. (2006)] was distinguished from closely related species, such as H. ovalis, H. minor, H. ovata Gaudichaud, and $H$. nipponica J. Kuo by two main characteristics: (i) the number of cross veins, which ranges from 18 to 22, and (ii) the ratio of the distance between the intramarginal vein and the lamina margin at the half-way point along the leaf length, which is 1:20-1:25 (Kuo et al. 2006). Recently, genetic markers, including plastid and nuclear sequences, have been used to reveal the genetic relationships among members of the genus Halophila. Among the molecular markers used, neither single sequence analysis of the plastid gene encoding the large subunit of ribulose1,5-bisphosphate-carboxylase-oxygenase $(r b c \mathrm{~L})$ and of the plastid maturase $\mathrm{K}$ (matK) nor analysis of the concatenated sequences of the two plastid markers has resolved the two closely related species $H$. ovalis and $H$. ovata (Lucas et al. 2012). In contrast, using phylogenetic analyses of the nuclear ribosomal internal transcribed spacer (ITS1-5.8S-ITS2) region showed that some specimens identified as $H$. ovalis belonged to different clades, and this clearly points to the need for critical taxonomic revision of Halophila material across the entire geographical range of this genus (Waycott et al. 2002). A reassessment of Halophila species from Japan based on ITS sequences indicated that $H$. major and $H$. ovalis are distinct species (Uchimura et al. 2008), which supported investigations by Kuo et al. (2006). Studies of ITS sequences have reported little or no nucleotide difference between individual $\mathrm{Hal}$ ophila species, such as H. nipponica (Shimada et al. 2012), H. hawaiiana Doty and B. C. Stone (McDermid et al. 2003), and H. stipulacea (Forss.) Ascherson (Ruggiero and Procaccini 2004), although the species varied considerably in leaf morphology. However, the ITS marker was a useful tool to reveal new records of $H$. decipiens for regions, such as the Hawaiian Islands (McDermid et al. 2002) and Kenya (McMahon and Waycott 2009). ITS sequences also indicated that $H$. johnsonii Eiseman and H. ovalis were synonyms (Short et al. 2010). The results of Uchimura et al. (2008) based on ITS sequences suggest that $H$. gaudichaudii J. Kuo, H. okinawensis J. Kuo, and H. nipponica may be conspecific.

Our initial studies based on morphology and analysis of genetic markers ( $r b c \mathrm{~L}$ and matK) indicated that $H$. ovalis collected at Nha Trang Bay showed different traits in comparison with other $H$. ovalis populations 
in Vietnam, although there were no nucleotide differences among $r b c \mathrm{~L}$ sequences and only one different base pair among matK sequences of the collections (Nguyen et al. 2013). This led to the hypothesis that phylogenetic analysis based on ITS sequences would resolve the taxonomic uncertainties among specimens of Halophila from Nha Trang, and clarify the status of Halophila species in Vietnam. There have been no previous records of $H$. major in Vietnam (Tien et al. 2002), although it occurs in neighboring countries, such as Indonesia and Thailand (Uchimura et al. 2008). This study documents a new record for H. major in Vietnam. The morphology, location, and habitats of $H$. major are described, and a molecular phylogeny is presented showing the position of H. major from Vietnam in a Western Pacific context.

\section{Materials and methods}

Plants of Halophila species (H. beccarii, $H$. decipiens, and $H$. ovalis) were collected from five different locations: Thi Nai Lagoon, Cu Mong Lagoon, Van Phong Bay, Nha Trang Bay, and Thuy Trieu Lagoon along the coastal central provinces in Vietnam (Figure 1) by SCUBA diving or snorkeling in depths of 1-6 m. Sections of plants about $10-12 \mathrm{~cm}$ long in a developmentally comparable state were collected haphazardly from 10 to 15 different plants, which were separated by $10-15 \mathrm{~m}$ to avoid collecting from the same clone. These plant sections consisting of intact roots, rhizome, and leaves were washed with seawater in the field to remove epiphytes and debris that were attached to the plants. Each plant sample was sorted by species, placed in a single plastic bag, kept on ice, and transferred to the laboratory on the same day. In the laboratory, samples were rewashed with deionized water to remove seawater. Each plant was divided into two parts, one was pressed as an herbarium voucher specimen and the other was stored in high-salt cetyltrimethylammonium bromide (CTAB) buffer (Štorchová et al. 2000) for later DNA extraction and morphological analysis. Herbarium voucher specimens are currently deposited at the Institute of Oceanography, Nha Trang City, Vietnam. Material stored in CTAB buffer was brought to the Institute of Botany, Leibniz University Hannover, Germany, for further analysis. Ten mature leaves were selected from 10 different plants of each species for morphological measurements, including lamina width, distance from intramarginal vein to lamina margin, cross-vein angle, and the number of cross veins. The ratio between intramarginal veins and the width at the half-length of the lamina was calculated.
Specimens were identified using the keys of den Hartog (1970) and Kuo et al. (2006).

Leaves were washed with deionized water to remove CTAB buffer completely. Eight to 10 young leaves from one individual of each species were homogenized by mortar and pestle in liquid nitrogen, and $100 \mathrm{mg}$ of the finely powdered plant material was used for DNA extraction. DNA extraction was carried out using the Plant Nucleospin II Kit (Macherey \& Nagel, Düren, Germany) following manufacturer's instructions with slight modifications according to Lucas et al. (2012). The region selected for PCR amplification was the nuclear ITS region including the $5.8 \mathrm{~S}$ sequence. Primer pairs used in this study were P674 5'-CCTTATCATTTAGAGGAAGGAG-3' (ITS5a) (Stanford et al. 2000) and P675 5'-TCCTCCGCTTATTGATATGC-3' (ITS4) (White et al. 1990) to amplify a sequence of 700-720 bp consisting of ITS1, 5.8S, and ITS2. The total volume of $25 \mu$ included $1 \times$ Dream Taq Green buffer, $0.2 \mathrm{~mm}$ dNTPs, $2 \mathrm{~mm} \mathrm{MgCl}, 1 \mathrm{U} \mathrm{Taq}$ polymerase (MBI Fermentas, St. Leon-Rot, Germany), 10-30 ng template DNA, and 1 pmol of each primer. PCR was performed in a PTC 200 thermocycler (Biozym-Diagnostik GmbH, Hess Oldendorf, Germany) with a heated lid under the following conditions: initial denaturation for $4 \mathrm{~min}$ at $95^{\circ} \mathrm{C}$ followed by 30 cycles of denaturation for $25 \mathrm{~s}$ at $95^{\circ} \mathrm{C}$, primer annealing for $30 \mathrm{~s}$ at $52^{\circ} \mathrm{C}$, and extension for $35 \mathrm{~s}$ at $72^{\circ} \mathrm{C}$, terminated by a final hold at $10^{\circ} \mathrm{C}$. All PCR reactions were repeated two to four times independently with the same individual to keep errors (possibly created by the Taq polymerase) in the final consensus sequence to a minimum. Direct sequencing of PCR product was done by GATC Biotech (Konstanz, Germany) from both directions. Consensus sequence was achieved by Clone Manager 9 (Sci-Ed, Cary, NC, USA). For comparison, known ITS sequences of other Halophila species were added to the dataset (Table 1). These sequences were aligned by CLUSTAL X (Thompson et al. 1997), and the alignment was further modified by eye. Gaps were considered as missing data. Identical sequences within each species were excluded from the alignment. Additional in-group sequences were obtained from GenBank (Table 1), and included in the alignment. Halophila angelmannii Ascherson (AF366404) and $H$. beccarii Ascherson (AF366441) were used as outgroup (Waycott et al. 2002). The program jModelTest 0.1.1 (Posada 2008) was used to find the model of sequence evolution that fitted the data set best. Phylogenetic analyses were performed using maximum likelihood, neighbor joining (Saitou and Nei 1987) with the model Tamura 3-parameter $+\mathrm{G}$, maximum parsimony (Felsenstein 1992) in MEGA5 (Tamura et al. 2011), and Bayesian analysis (metropolis-coupled Markov chain Monte Carlo method) 


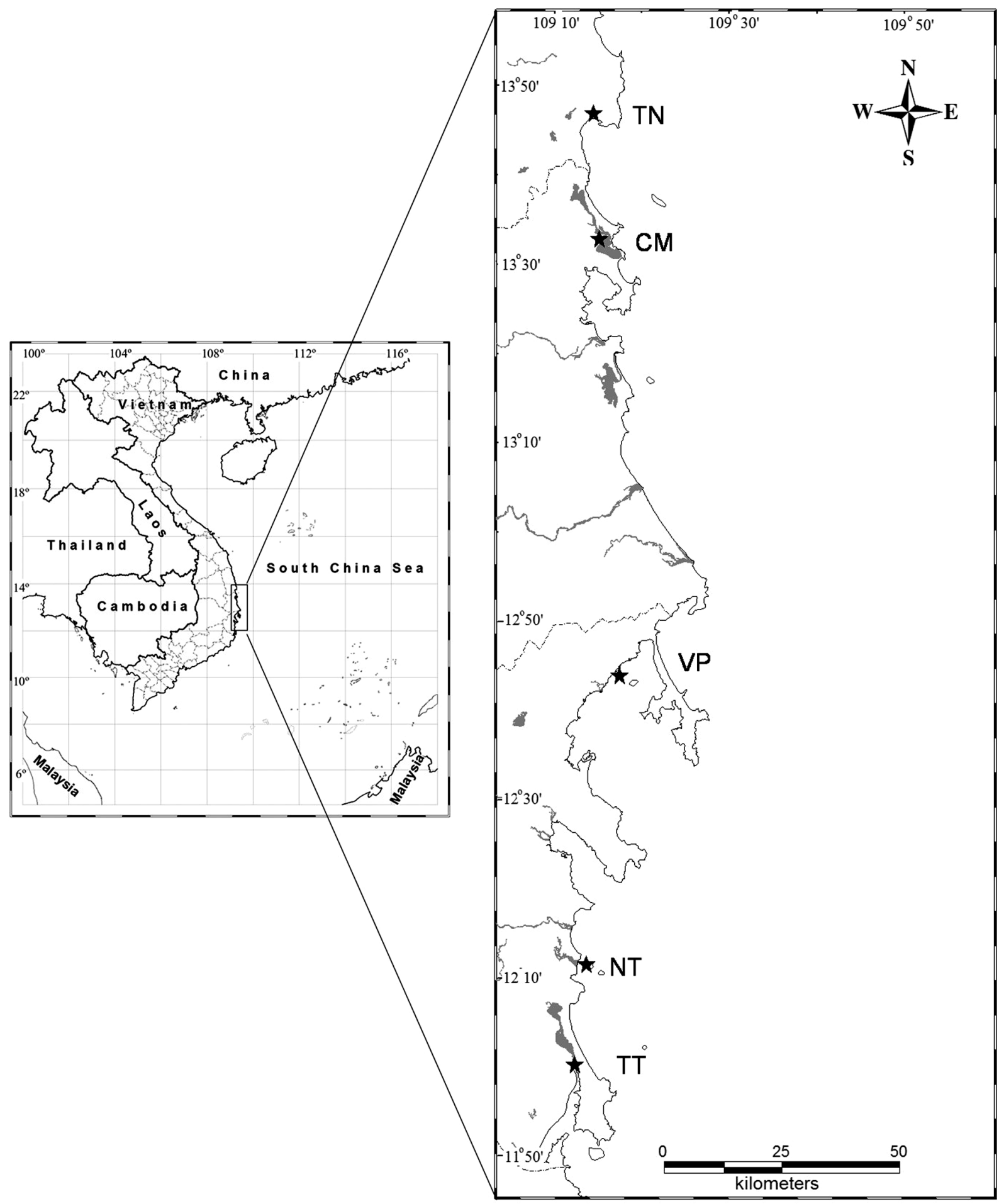

Figure 1 Sample collection sites ( $\star$ ) for Halophila surveys in Vietnam.

TN, Thi Nai Lagoon; CM, Cu Mong Lagoon; VP, Van Phong Bay; NT, Nha Trang Bay; TT, Thuy Trieu Lagoon. (Source: Digital map, Department of Survey and Mapping, Ministry of Natural Resources and Environment, Vietnam.)

performed in MrBayes v.3.1.2 (Ronquist et al. 2011). In the Bayesian analysis, the two parallel runs with four chains each (three heated and one cold) were run for 1 million generations, sampling a tree every 100 generations. Only trees sampled after convergence were used to make inferences about the phylogeny and to compute a 50\% majority-rule consensus tree. In the analyses, trees were tested by the bootstrapping method with 1000 replications. 
Table 1 List of the Halophila taxa included in the molecular analysis done in this study.

\begin{tabular}{|c|c|c|c|}
\hline Taxa & Geographic source & Citation & $\begin{array}{l}\text { GenBank accession } \\
\text { number }\end{array}$ \\
\hline H. beccarii Ascherson & Gia Luan, Vietnam & Waycott et al. (2002) & AF366441 \\
\hline H. beccarii Ascherson & Thuy Trieu, Vietnam & This study & KC175914 ${ }^{\mathrm{a}}$ \\
\hline H. engelmannii Ascherson & Florida, USA & Waycott et al. (2002) & AF366404 \\
\hline H. spinulosa (R. Brown) Ascherson & Malaysia & Waycott et al. (2002) & AF366440 \\
\hline H. tricostata Greenway & Australia & Waycott et al. (2002) & AF366438 \\
\hline H. decipiens Ostenfeld & Florida, USA & Waycott et al. (2002) & AF366407 \\
\hline H. decipiens Ostenfeld & Costa Rica & Waycott et al. (2002) & AF366409 \\
\hline H. decipiens Ostenfeld & Malaysia & Waycott et al. (2002) & AF366412 \\
\hline H. decipiens Ostenfeld & Nakagusuku, Japan & Uchimura et al. (2006) & AB243979 \\
\hline H. decipiens Ostenfeld & Nakagusuku, Japan & Uchimura et al. (2006) & AB243980 \\
\hline H. decipiens Ostenfeld & Oaura, Japan & Uchimura et al. (2006) & AB243984 \\
\hline H. decipiens Ostenfeld & Izena Island, Japan & Uchimura et al. (2006) & AB243982 \\
\hline H. decipiens Ostenfeld & Nha Trang, Vietnam & This study & KC175913 \\
\hline H. stipulacea (Forsskäl) Anderson & Italy & Waycott et al. (2002) & AF366436 \\
\hline H. major (Zoll.) Miquel & Bali, Indonesia & Uchimura et al. (2006) & AB436928 \\
\hline H. major (Zoll.) Miquel & Sumbawa, Indonesia & Uchimura et al. (2006) & AB436926 \\
\hline H. major (Zoll.) Miquel & Kagoshima, Japan & Uchimura et al. (2006) & AB436929 \\
\hline H. major (Zoll.) Miquel ${ }^{b}$ & Nha Trang, Vietnam & This study & KC175910 \\
\hline H. nipponica J. Kuo & Odawa Bay, Japan & Uchimura et al. (2006) & AB436931 \\
\hline H. nipponica J. Kuo & Mutsu Bay, Japan & Uchimura et al. (2006) & AB436932 \\
\hline H. nipponica J. Kuo & Suou-Ohshima, Japan & Uchimura et al. (2006) & AB436933 \\
\hline H. minor (Zollinger) den Hartog & Philippines & Waycott et al. (2002) & AF366405 \\
\hline H. minor (Zollinger) den Hartog & Guam & Waycott et al. (2002) & AF366406 \\
\hline H. ovalis (R. Brown) Hooker $f$. & Flores Island, Indonesia & Uchimura et al. (2008) & AB436940 \\
\hline H. ovalis (R. Brown) Hooker $f$. & Dingo Beach, Australia & Waycott et al. (2002) & AF366431 \\
\hline H. ovalis (R. Brown) Hooker $f$. & Trang, Thailand & Uchimura et al. (2008) & AB436939 \\
\hline H. ovalis (R. Brown) Hooker $f$. & Trang, Thailand & Uchimura et al. (2008) & AB436938 \\
\hline H. ovalis (R. Brown) Hooker $f$. & Nakagusuku, Japan & Uchimura et al. (2008) & AB243973 \\
\hline H. ovalis (R. Brown) Hooker $f$. & Kayou, Japan & Uchimura et al. (2008) & AB243974 \\
\hline H. ovalis (R. Brown) Hooker $f$. & Kabila, Japan & Uchimura et al. (2008) & AB243975 \\
\hline H. ovalis (R. Brown) Hooker $f$. & Taketomi Island, Japan & Uchimura et al. (2008) & AB243976 \\
\hline H. ovalis (R. Brown) Hooker $f$. & Thuy Trieu, Vietnam & This study & KC175908 \\
\hline H. ovalis (R. Brown) Hooker $f$. & Van Phong, Vietnam & This study & KC175909a \\
\hline H. ovalis (R. Brown) Hooker $f$. & Thi Nai, Vietnam & This study & KC175911 ${ }^{\mathrm{a}}$ \\
\hline H. ovalis (R. Brown) Hooker $f$. & Cu Mong, Vietnam & This study & KC175912 ${ }^{\mathrm{a}}$ \\
\hline
\end{tabular}

${ }^{a}$ Accession number was deposited in GenBank.

${ }^{b}$ First identification as $H$. ovalis.

Bold: Samples collected in the present study.

Sequence divergences and nucleotide differences were also calculated by Tamura 3-parameter model with gamma distribution in MEGA5 (Tamura et al. 2011).

\section{Results}

This study shows for the first time that Halophila major (Figure 2), formerly identified as H. ovalis (Dai et al. 1998, Tien 2008), grows at Tre Island, Nha Trang Bay, at a depth of 4-6 $\mathrm{m}$ in patches within a mixed meadow of Halodule uninervis (Forssk.) Boiss, Halodule pinifolia (Miki) Hartog, and Syringodium isoetifolium (Asch.) Dandy. This is a new record for this seagrass species in Vietnam and expands its known geographical range northward. Both morphological and genetic analyses of specimens distinguished it as H. major.

The following leaf morphology was observed: lamina bright to dark green, oblong, paired leaves, without serrated leaf margins, lamina width $9-11 \mathrm{~mm}$, length of mature leaves $15-18 \mathrm{~mm}$, number of cross veins $18-22$, and distance from intramarginal vein to lamina margin $0.20-0.25 \mathrm{~mm}$. At the half-length point of the leaf, the ratio of the distance between intramarginal vein 


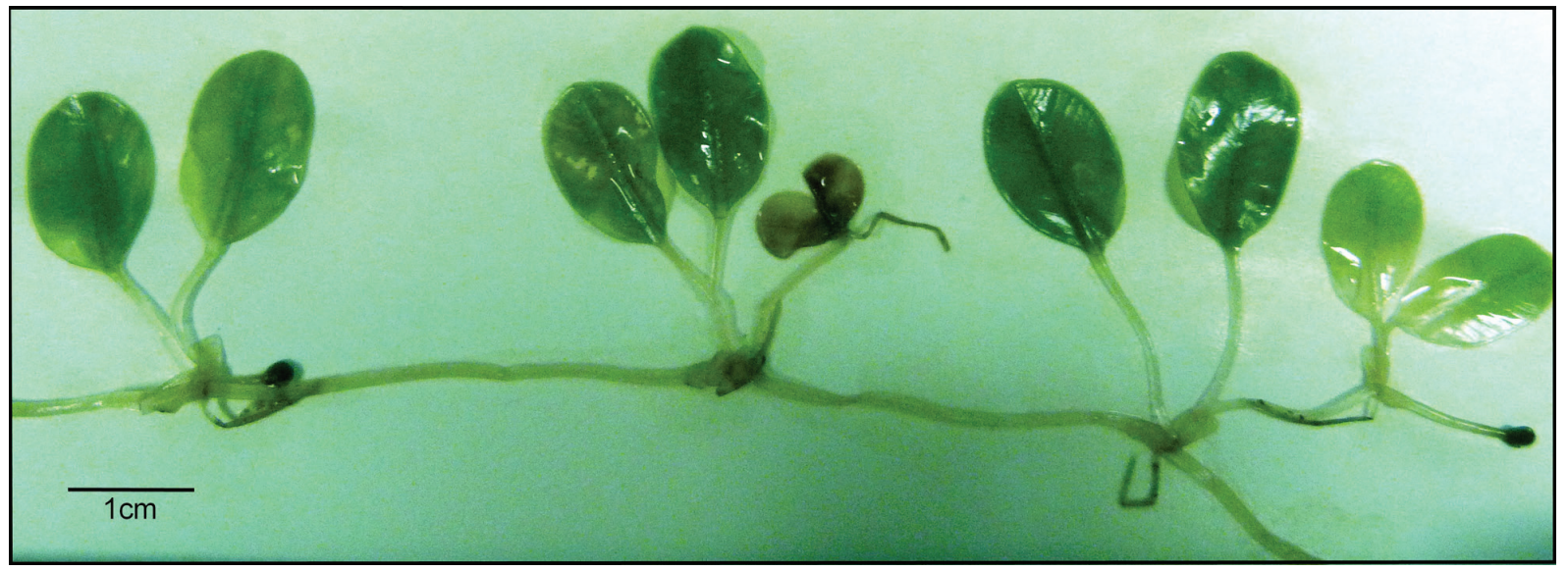

Figure 2 Fragment of wet living specimen of Halophila major collected from Nha Trang.

and lamina margin was 1:20-1:25. Cross-vein branching was very common, and cross-vein angle ranged from $45^{\circ}$ to $60^{\circ}$.

On the basis of our data on leaf morphology, we conclude that only $\mathrm{H}$. major and no $\mathrm{H}$. ovalis was collected at Nha Trang Bay. Comparisons of the leaf morphology of $H$. major collected at Nha Trang Bay (Figure 3A) and that of $H$. ovalis collected at other locations (Figure 3B-E) showed differences in two leaf morphological traits: (i) the ratio of the distance between the intramarginal vein and the lamina margin (1:20-1:25 in H. major; 1:12-1:17 in $H$. ovalis) and (ii) the number of cross veins $(<16$ in H. ovalis; $>16$ in H. major). A detailed comparison of the leaf morphology of the two species is presented in Table 2 and Figure 3A-E. Direct comparison among specimens of $\mathrm{H}$. ovalis collected from Thi Nai, Cu Mong, Van Phong, and Thuy Trieu, and H. major (originally identified as $H$. ovalis) collected in Nha Trang clearly indicated that
H. ovalis specimens collected at Nha Trang were H. major (Table 2, Figure 3A-E).

\section{Genetic analyses}

A set of 36 ITS sequences and 620 characters (nucleotides and gaps) covering ITS1, 5.8S, and ITS2 from the genus Halophila were included in our analysis. Only five nucleotides were different between Halophila major collected in Vietnam and the published sequence data for H. major (Uchimura et al. 2008; for collection locations, see Table 1; data not shown), whereas 24-30 nucleotide differences (data not shown) were found between $H$. major collected at Nha Trang Bay and H. ovalis collected in other locations in Vietnam (Table 1). In addition, evolutionary divergence between our sequence data and published $H$. major sequences is very low (0.009), while

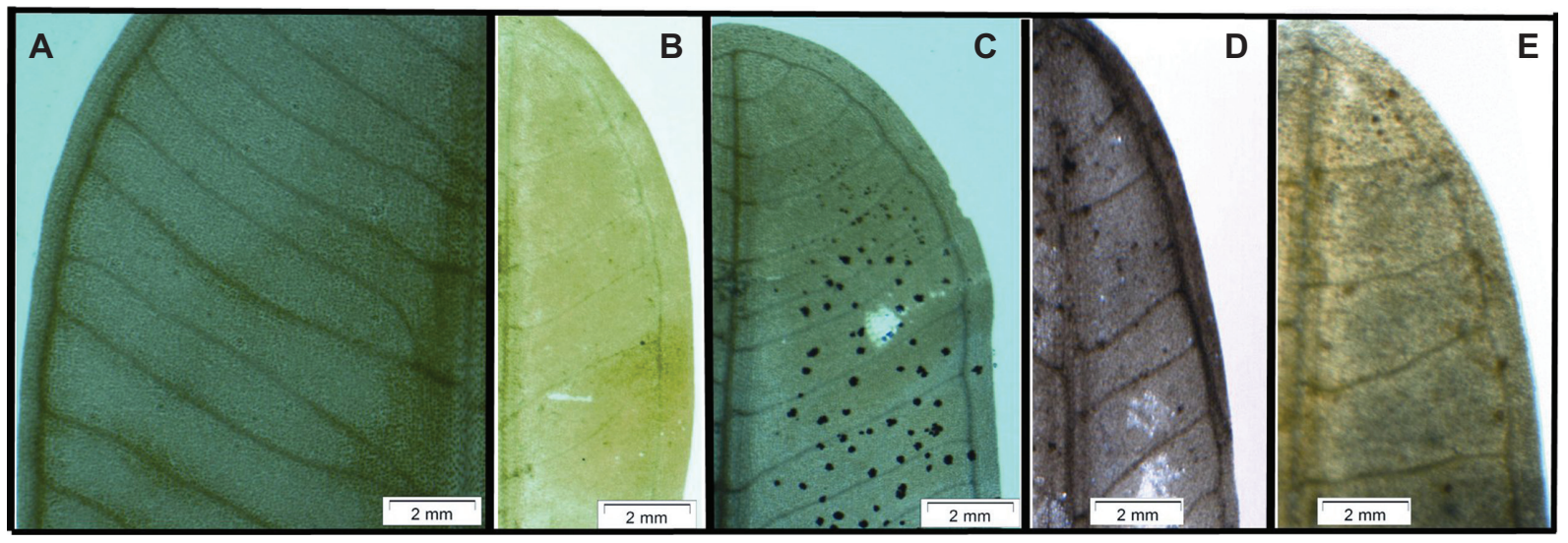

Figure 3 Comparison of leaf morphology of $H$. major and $H$. ovalis specimens collected in Vietnam.

(A) H. major, (B) H. ovalis (TT), (C) H. ovalis (VP), (D) H. ovalis (CM), and (E) H. ovalis (TN). Abbreviations as in Figure 1. 
Table 2 Comparisons of leaf morphology of $H$. major and additional $H$. ovalis species collected in Vietnam and previous studies.

\begin{tabular}{|c|c|c|c|c|c|c|c|}
\hline \multirow[t]{2}{*}{ Characteristic } & \multicolumn{7}{|l|}{ Species } \\
\hline & H. ovalis & H. ovalis TT & H. ovalis VP & H. ovalis CM & H. ovalis TN & H. major NT & H. major \\
\hline Lamina width (mm) & $5-20$ & $5-7$ & $6-7$ & $3.7-4.7$ & $6-7$ & $9-12$ & $9-11$ \\
\hline Lamina length (mm) & $10-40(-70)$ & $9-12$ & $8-11$ & $8-11$ & $8.5-11.7$ & $10-18$ & $15-25$ \\
\hline No. of paired cross veins & $10-25$ & $8-12$ & $12-16$ & $8-10$ & $12-16$ & $16-22$ & $14-17$ \\
\hline $\begin{array}{l}\text { Space between } \\
\text { intramarginal veins }(\mathrm{mm})\end{array}$ & $0.1-0.3$ & 0.2 & 0.2 & 0.2 & 0.2 & $0.2-0.25$ & 0.2 \\
\hline Cross-vein branching & Common & Common & Occasional & Rarely & Common & Common & Common \\
\hline Cross-vein angles & $45^{\circ}-60^{\circ}$ & $50^{\circ}-70^{\circ}$ & $60^{\circ}-80^{\circ}$ & $45^{\circ}-50^{\circ}$ & $60^{\circ}-80^{\circ}$ & $60^{\circ}-80^{\circ}$ & $45^{\circ}-60^{\circ}$ \\
\hline $\begin{array}{l}\text { Half lamina width: distance } \\
\text { between intramarginal veins } \\
\text { and lamina margin ratio }\end{array}$ & $\mathrm{n} / \mathrm{a}$ & $1: 12-17$ & $1: 15-17$ & $1: 9-11$ & $1: 15-17$ & $1: 24-25$ & $1: 20-25$ \\
\hline Source & den Hartog (1970) & This study & This study & This study & This study & This study & Kuo et al. (2006) \\
\hline
\end{tabular}

$\mathrm{n} / \mathrm{a}$, not available.

The abbreviations are explained in the legend to Figure 1.

evolutionary divergence between our data and $H$. ovalis is much higher (0.043-0.051; data not shown). In this study, four methods were used to construct the phylogenetic trees. There was no difference in the topology of the phylogenetic trees based on these different methods except for small differences in the bootstrap values. The tree-based approaches showed that $H$. major collected in Vietnam grouped with $H$. major collected from other locations (Figure 4).

\section{Discussion}

The highlight of this study is that Halophila major, a common species in the Western Pacific region, is recorded as a new species in Vietnam, increasing the known number of Halophila species in Vietnam to five. Variation of leaf morphology has been detected within several species of the Halophila genus, namely $H$. ovalis (Annaletchumy et al.2005, Hedge etal.2009), H. hawaiana (McDermid et al. 2003), and H. nipponica (Shimada et al. 2012). Molecular markers, especially ITS, were shown to be a valuable tool in resolving genetic relationships among the species of Halophila. For instance, Halophila euphlebia was once treated as synonym for $H$. ovalis (Miki 1934, den Hartog 1970); then, this species was transferred to H. major (Kuo et al. 2006). Results of Uchimura et al. (2008) and Shimada et al. (2012) supported the conclusion of Kuo et al. (2006) that H. major and H. ovalis are distinct species. In this study, leaf morphological parameters, including the distance between intramarginal veins, the lamina-to-margin ratio, and the number of cross veins, indicated that Halophila specimens collected at Nha Trang Bay in 2011 were much closer to H. major as described by Kuo et al. (2006) than to H. ovalis. Direct morphological comparison among specimens of $H$. ovalis collected from Thi Nai, Cu Mong, Van Phong, and Thuy Trieu, and the Halophila species collected in Nha Trang, which was originally identified as $H$. ovalis, clearly indicated this species is $H$. major. Our phylogenetic analysis also clarified the evolutionary relationships between Vietnamese H. major and other populations of $H$. major collected in the Western Pacific region. The topology of the phylogenetic tree derived from four methods does not reveal any differences, except slightly different bootstrap values at some nodes. All methods indicated that $H$. major and $H$. ovalis are distributed in two distinct clades. Moreover, nucleotide differences and evolutionary divergence within the H. major clade, including H. major from Vietnam, are much lower than between the H. major clade and $H$. ovalis. Our leaf morphological and phylogenetic analyses support the evidence from previous studies (Kuo et al. 2006, Uchimura et al. 2008, Shimada et al. 2012) that $H$. major and H. ovalis are distinct species. In contrast, Short et al. $(2007,2011)$ argued that the taxonomy of $H$. major was unclear because of overlapping leaf characteristics between $H$. ovalis and H. major. However, Short et al. (2011) suggested that the species should be accepted if supported by genetic data.

In terms of morphology, Waycott et al. (2002) stated that the basal group [H. engelmanii, $H$. beccarii, H. tricostata Greenway, and H. spinulosa (R. Brown) Ascherson] in this genus belongs to the more structurally complex species. Greater diversity of morphological and genetic traits was found in the simple phyllotaxy group 


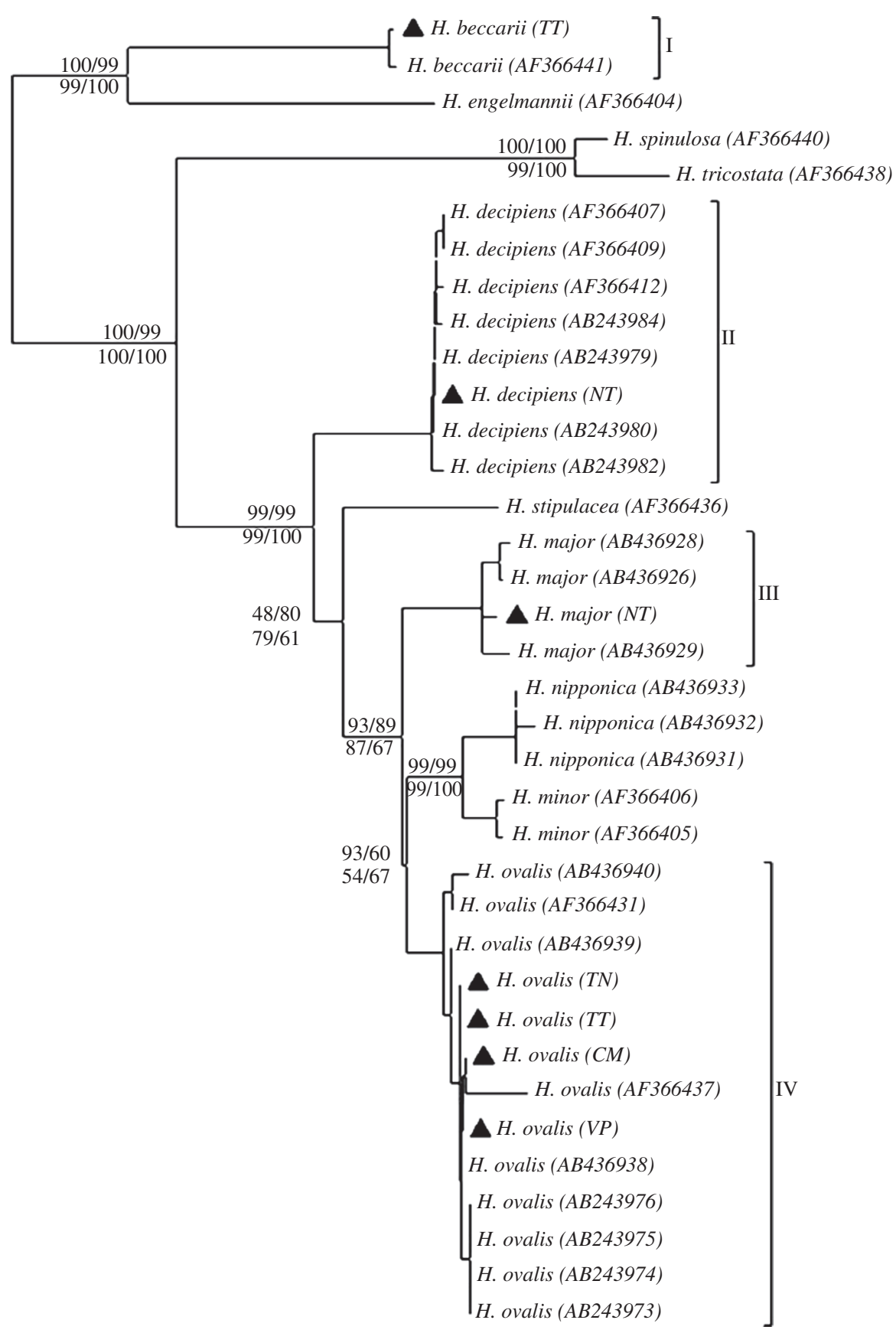

Figure 4 Phylogeny of Halophila inferred from maximum likelihood, neighbor joining, maximum parsimony, and Bayesian analysis based on $620 \mathrm{bp}$ (including gaps) of nrDNA sequences comprising ITS-1, 5.8S rDNA, and ITS-2.

The specimens collected from Vietnam are marked by bold triangles. The bootstrap value of each method is shown in each node: above nodes, left: maximum likelihood, right: neighbor joining; below nodes, left: maximum parsimony, right: Bayesian analysis. Abbreviations as in Figure 1.

(two leaves per shoot). Recently, a study conducted on generic phylogeny, historical biogeography, and evolution of the Hydrocharitaceae indicated that Halophila possibly originated in Southeast Asia 15.9-41.3 million years ago (Chen et al. 2012). The H. ovalis complex can be found in different environmental conditions with high morphological variability (den Hartog 1970). Waycott et al. (2002) suggested that the variation may be genotypically determined, as for $\mathrm{H}$. major. Further molecular marker studies may show whether $H$. major is a recent immigrant to Vietnam or was just not recognized as this species by previous collectors. 
Acknowledgments: We are deeply indebted to all staff at the Institute of Botany, Leibniz University Hannover, Germany, and at the Department of Marine Botany, Institute of Oceanography, Vietnam, for kind support in the laboratory work and sample collection. Special and sincere thanks are also due to Prof. Dr. Karla McDermid (Hawaii University at Hilo, USA) for critically reading the manuscript and generously providing many valuable suggestions. This research was financially supported by the Leibniz University Hannover, Germany, and the Government of Vietnam.

Received 1 August, 2012; accepted 25 June, 2013; online first 24 July, 2013

\section{References}

Annaletchumy, L., S. Japar, H. Muta Harah and A. Arshad. 2005. Morphology of Halophila ovalis (R.Br.) Hook. f. from Peninsular and East Malaysia. Pertanika J. Trop. Agric. Sci. 28: 1-12.

Chen, L.Y., J.M. Chen, R.W. Gituru and Q.F. Wang. 2012. Generic phylogeny, historical biogeography and character evolution of the cosmopolitan aquatic plant family Hydrocharitaceae. BMC Evol. Biol. 12:30.

Dai, N.H., P.H. Tri, N.X. Hoa and N.T. Linh. 1998. Seagrass beds in the South of Vietnam. Proc. 4th Nat. Conf. Mar. Sci. Tech. 2: 967-972.

den Hartog, C. 1970. The sea-grasses of the world. North-Holland, Amsterdam Publishing Company, Amsterdam. pp. 257.

Felsenstein, J. 1992. Phylogenies from restriction sites: a maximum-likelihood approach. Evolution 46: 159-173.

Hedge, S., N. Smith and R.K.F. Unsworth. 2009. Temporal and spatial morphological variability of the seagrasses Halophila ovalis and Halodule uninervis throughout the Great Barrier Reef region: preliminary analysis. Report to the Marine and Tropical Sciences Research Facility. Reef and Rainforest Research Centre Limited, Cairns. pp. 15.

Kuo, J., Z. Kanomoto, H. lizumi and H. Mukai. 2006. Seagrasses of the genus Halophila Thours (Hydrocharitaceae) from Japan. Acta Phytotax. Geobot. 57: 129-154.

Lucas, C., T. Thangaradjou and J. Papenbrock. 2012. Development of a DNA barcoding system for seagrasses: successful but not simple. PLoS One 7: e29987.

McDermid, K.J., M.C. Gregoritza and D.W. Freshwater. 2002. A new record of a second seagrass species from the Hawaiian archipelago: Halophila decipiens Ostenfeld. Aquat. Bot. 74: 257-262.

McDermid, K.J., M.C. Gregoritza, J.W. Reeves and D.W. Freshwater. 2003. Morphological and genetic variation in the endemic sea grass Halophila hawaiiana (Hydrocharitaceae) in the Hawaiian Archipelago. Pac. Sci. 57: 199-209.

McMahon, K.M. and M. Waycott. 2009. New record for Halophila decipiens Ostenfeld in Kenya based on morphological and molecular evidence. Aquat. Bot. 91: 318-320.

Miki, S. 1934. On the sea-grasses in Japan (II): Cymodocea and marine Hydrocharitaceae. Bot. Mag. Tokyo 48: 131-141.

Nguyen, X.V., J.S. Bujang and J. Papenbrock. 2013. Variability of leaf morphology and marker genes of members of the Halophila complex collected in Vietnam. Aquat. Bot. 10.1016/j. aquabot.2013.04.003. Available online 13 May 2013

Posada, D. 2008. jModelTest: phylogenetic model averaging. Mol. Biol. Evol. 25: 1253-1256.
Ronquist, F., J. Huelsenbeck and M. Teslenko. 2011. MRBAYES 3.2: Bayesian phylogenetic inference under mixed models. Bioinformatics 19: 1572-1574.

Ruggiero, M.V. and G. Procaccini. 2004. The rDNA ITS region in the Lessepsian marine angiosperm Halophila stipulacea (Forssk.) Aschers. (Hydrocharitaceae): intragenomic variability and putative pseudogenic sequences. Mol. Evol. 58: 115-121.

Saitou, N. and M. Nei. 1987. The neighbor-joining method: a new method for reconstructing phylogenetic trees. Mol. Biol. Evol. 4: 406-425.

Shimada, S., M. Watanabe, K. Ichihara and M. Uchimura. 2012. Morphological variations of seagrass species, Halophila nipponica (Hydrocharitaceae, Alismatales). Coast. Mar. Sci. 35: 85-90.

Short, F.T., W.C. Dennison, T.J.B. Carruthers and M. Waycott. 2007. Global seagrass distribution and diversity: a bioregional model. J. Exp. Mar. Biol. Ecol. 350: 3-20.

Short, F.T., G.E. Moore and K.A. Peyton. 2010. Halophila ovalis in the tropical Atlantic Ocean. Aquat. Bot. 93: 141-146.

Short, F.T., B. Polidoro, S.R. Livingstone, K.E. Carpenter, S. Bandeira, J.S. Bujang, H.P. Calumpong, T.J.B. Carruthers, R.G. Coles, W.C. Dennison, P.L.A. Erftemeijer, M.D. Fortes, A.S. Freeman, T.G. Jagtap, A.H.M. Kamal, G.A. Kendrick, W.J. Kenworthy, Y.A. LaNafie, I.M. Nasution, R.J. Orth, A. Prathep, J.C. Sanciangco, B.V. Tussenbroek, S.G. Vergara, M. Waycott and J.C. Zieman. 2011. Extinction risk assessment of the world's seagrass species. Biol. Conserv. 144: 1961-1971.

Stanford, A.M., R. Harden and C.R. Parks. 2000. Phylogeny and biogeography of Juglans (Juglandaceae) based on matK and ITS sequence data. Am. J. Bot. 87: 872-882.

Štorchová, H., R. Hrdličková, J. Chrtek Jr., M. Tetera, D. Fitze and J. Fehrer. 2000. An improved method of DNA isolation from plants collected in the field and conserved in saturated $\mathrm{NaCl}$ / CTAB solution. Taxon 49: 79-84.

Tamura, K., D. Peterson, N. Peterson, G. Stecher, M. Nei and S. Kumar. 2011. MEGA5: molecular evolutionary genetics analysis using maximum likelihood, evolutionary distance, and maximum parsimony methods. Mol. Biol. Evol. 28: 2731-2739.

Thompson, J.D., T.J. Gibson, F. Plewniak, F. Jeanmougin and D.G. Higgins. 1997. The CLUSTAL X windows interface: flexible strategies for multiple sequence alignment aided by quality analysis tools. Nucl. Acids Res. 25: 4876-4882.

Tien, N.V. 2008. National report on seagrass in the South China Sea. United Nations Environment Programme. Reversing environmental degradation trends in the South China Sea and Gulf of Thailand. pp. 33. 
Tien, N.V., D.N. Thanh and N.H. Dai. 2002. Seagrasses in Vietnam. Sci. \& Tech. Publ. House, Hanoi. pp. 167. (in Vietnamese).

Uchimura, M., E.J. Faye, S. Shimada, S. Arai, T. Inoue and Y. Nakamura. 2006. A re-evaluation of the taxonomic status of Halophila euphlebia Makino (Hydrocharitaceae) based on morphological features and ITS sequence data. Bot. Mar. 49: 111-121.

Uchimura, M., E.J. Faye, S. Shimada, S. Arai, T. Inoue and Y. Nakamura. 2008. A reassessment of Halophila species (Hydrocharitaceae) diversity with special reference to Japanese representatives. Bot. Mar. 51: 258-268.
Waycott, M., D. Freshwater, R. York, A. Calladine and W. Kenworthy. 2002. Evolutionary trends in the seagrass genus Halophila (Thouars): insights from molecular phylogeny. Bull. Mar. Sci. 71: 1299-1308.

White, T.J., T. Bruns, S. Lee and J.W. Taylor. 1990. Amplification and direct sequencing of fungal ribosomal RNA genes for phylogenetics. In: (M.A. Innes, D.H. Delfand, J.J. Sninsky and T.J. White, eds.) PCR protocols: a guide to methods and applications. Academic Press, New York. pp. 315-322. 